\title{
GAN wt Allele
}

National Cancer Institute

\section{Source}

National Cancer Institute. GAN wt Allele. NCI Thesaurus. Code C106423.

Human GAN wild-type allele is located in the vicinity of $16 q 24.1$ and is approximately 65 $\mathrm{kb}$ in length. This allele, which encodes gigaxonin protein, is involved in both ubiquitination and neurofilament structure. Mutation of the gene is associated with giant axonal neuropathy. 